\title{
Production of Thiol-dependent Haemolysins by Listeria monocytogenes and Related Species
}

\author{
By CHRISTIANE GEOFFROY, ${ }^{1} \mathrm{JEAN}$-LOUIS GAILLARD, ${ }^{2}$ \\ JOSEPH E. ALOUF ${ }^{1}$ AND PATRICK BERCHE ${ }^{2 *}$ \\ ${ }^{1}$ Unité des Antigènes Bactériens (Centre National de la Recherche Scientifique, UA 040557), \\ Institut Pasteur, 75724 Paris Cedex 15, France \\ ${ }^{2}$ Faculté de Médecine Necker-Enfants Malades, Laboratoire de Microbiologie, 75730 Paris \\ Cedex 15, France
}

(Received 11 July 1988; revised 31 October 1988; accepted 15 November 1988)

\begin{abstract}
Twenty-six strains belonging to the five main species of the genus Listeria were examined for production of thiol-dependent exotoxins. All strains of $L$. monocytogenes cultured in charcoaltreated broth secreted a haemolytic factor at a level ranging from 200 to 800 haemolytic units (HU) $\mathrm{ml}^{-1}$, except for the strain EGD $\left(1500 \mathrm{HU} \mathrm{ml}^{-1}\right)$ and the type strain CIP 82110T $\left(10 \mathrm{HU} \mathrm{ml}^{-1}\right)$. The haemolytic activity reached a maximum level by $8-10 \mathrm{~h}$ and then rapidly declined as soon as bacterial exponential growth ceased. The titres of haemolytic activity were markedly reduced when bacteria were grown in charcoal-untreated broth. The haemolytic factor produced by $L$. monocytogenes strains was characterized as listeriolysin $\mathrm{O}\left(M_{\mathrm{r}}\right.$ about 60000 ), a member of the group of thiol-dependent exotoxins. Strains of Listeria ivanovii also produced high levels of thiol-dependent exotoxin (about $2500 \mathrm{HU} \mathrm{ml}^{-1}$ ), in both charcoaltreated and untreated broth. Small amounts of haemolytic factor (about 9-30 $\mathrm{HU} \mathrm{ml}^{-1}$ ) were also produced by Listeria seeligeri in charcoal-treated broth. The haemolysin produced by $L$. seeligeri was identified for the first time as a thiol-dependent exotoxin of $M_{\mathrm{r}}$ about 60000 , antigenically related to listeriolysin $\mathrm{O}$. As expected, we failed to detect thiol-dependent exotoxin in the two nonhaemolytic species, Listeria innocua and Listeria welshimeri.
\end{abstract}

\section{INTRODUCTION}

Recent experimental evidence suggests that the production of an extracellular haemolysin constitutes a major mechanism promoting intracellular growth of Listeria monocytogenes (Gaillard et al., 1986; Kathariou et al., 1987; Portnoy et al., 1988), in both nonprofessional and professional phagocytes (Gaillard et al., 1987, Kuhn et al., 1988). The haemolytic factor from the virulent strain EGD has been purified and characterized as a $60 \mathrm{kDa}$ thiol-activated exotoxin, designated listeriolysin O (Geoffroy et al., 1987), antigenically related to streptolysin O (SLO) and fully active at pH 5.5. Its structural gene has been cloned by Vicente et al. (1985) and recently sequenced by Mengaud et al. (1988). Listeriolysin $O$ is a polypeptide of 529 amino acids (Mengaud et al., 1988), sharing strong homologies with SLO and pneumolysin (Kehoe \& Timmis, 1984; Mengaud et al., 1987; Walker et al., 1987). However, if this haemolytic factor is really of crucial importance for virulence, all virulent strains of $L$. monocytogenes should produce it. This prerequisite is apparently challenged by the finding of Parrisius et al. (1986) that only 2 out of 26 strains of $L$. monocytogenes secreted SLO-like haemolysin of $M_{\mathrm{r}} 55000-60000$, termed $\alpha$-listeriolysin. This was found by using a rabbit immune serum raised against partially purified SLO-like haemolysin obtained from Listeria ivanovii culture supernate. Consequently, it appears important to determine whether or not $L$. monocytogenes strains secrete a thiol-activated

Abbreviations: HU, haemolytic unit; SLO, streptolysin O; SRBC, sheep red blood cell. 
exotoxin. On the other hand, although L. ivanovii produces an SLO-like haemolysin (Parrisius et al., 1986), the nature of the haemolytic factor secreted by Listeria seeligeri remains unknown. The aim of this work was therefore to study the presence of thiol-activated exotoxins in the five main species of the genus Listeria.

\section{METHODS}

Bacterial strains and culture media. The 26 strains of Listeria used in this work are listed in Table 1 . These strains originated from culture collections, except for five clinical isolates (Hôpital Necker, Paris, France) obtained from blood or spinal fluid and subcultured only once or twice before storage at $-80^{\circ} \mathrm{C}$. Bacteria were grown in brain heart infusion broth (Diagnostics Pasteur), harvested in exponential-phase growth (about $10^{8}$ bacteria $\mathrm{ml}^{-1}$ ), and stored in $1 \mathrm{ml}$ portions at $-80^{\circ} \mathrm{C}$ until required. Viable bacteria were determined by plating $0.1 \mathrm{ml}$ of doubling dilutions on tryptic soy agar (Diagnostics Pasteur). Colony forming units (c.f.u.) were counted after $48 \mathrm{~h}$ of incubation at $37^{\circ} \mathrm{C}$.

Titration of haemolytic activity during bacterial growth. For the titration of haemolytic activity in culture supernates, bacteria were grown either in proteose-peptone broth [proteose-peptone no. 3 (Difco), $20 \mathrm{~g}$; yeast extract (Difco), $5 \mathrm{~g} ; \mathrm{Na}_{2} \mathrm{HPO}_{4} .12 \mathrm{H}_{2} \mathrm{O}, 8.3 \mathrm{~g} ; \mathrm{KH}_{2} \mathrm{PO}_{4}, 0.7 \mathrm{~g}$; quartz-distilled water to $1000 \mathrm{ml}$ or in charcoaltreated broth prepared as follows. A tenfold concentrated proteose-peptone broth (as described above) was supplemented with charcoal (Vegetable Activated Charcoal, Prolabo) at $0 \cdot 2 \%$ final concentration and the medium was stirred (100 r.p.m.) for $1 \mathrm{~h}$ at room temperature (Incubator Shaker, model G 25, New Brunswick Scientific). The charcoal-treated concentrate was further diluted in quartz-distilled water (1 in 10), adjusted to $\mathrm{pH} 7.5$ and autoclaved at $115^{\circ} \mathrm{C}$ for $20 \mathrm{~min}$. Sterile glucose to a final concentration of $1 \%$ was added before inoculation. The amount of iron in the medium was assessed at 6-8 $\mu \mathrm{M}$ by atomic absorption spectroscopy (Perkin-Elmer 403 apparatus). Preliminary assays showed that charcoal-treated medium gave the same results as the Chelex-treated medium previously described (Geoffroy et al., 1987), and it was used for convenience.

Bacteria were grown overnight in proteose-peptone broth or charcoal-treated broth, then $2.5 \mathrm{ml}$ volumes of the cultures were inoculated into $100 \mathrm{ml}$ of the same medium and incubated at $37^{\circ} \mathrm{C}$ without shaking. Bacterial growth was measured by optical density at $600 \mathrm{~nm}\left(\mathrm{OD}_{600}\right)$ in a Beckman $\mathrm{M} 25$ spectrophotometer, after brief centrifugation ( $1 \mathrm{~min}$ at $485 \mathrm{~g}$ ) of culture samples to remove charcoal particles. Samples ( $\mathrm{l} \mathrm{ml}$ ) of cultures were then centrifuged at $10000 \mathrm{~g}$ for $10 \mathrm{~min}$ at $4{ }^{\circ} \mathrm{C}$, and the supernatant fluid was assayed for haemolytic activity by the method of Alouf et al. (1965). Briefly, $0.5 \mathrm{ml}$ of $2.25 \%$ sheep red blood cell (SRBC) suspension $\left(6 \times 10^{8} \mathrm{ml}^{-1}\right)$ in

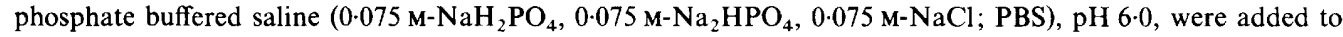
$1.0 \mathrm{ml}$ volumes of varying dilutions of supernates supplemented with cysteine $(20 \mathrm{mM}$ final concentration) in the same buffer supplemented with $0.1 \%$ bovine albumin (Sigma). After $45 \mathrm{~min}$ at $37^{\circ} \mathrm{C}$ the tubes were centrifuged at $1000 \mathrm{~g}$ for $30 \mathrm{~s}$ at $4{ }^{\circ} \mathrm{C}$ and haemoglobin in the supernate was measured by absorbance at $541 \mathrm{~nm}$ in a spectrophotometer (Beckman M25). One haemolytic unit (HU) is defined as the amount of toxin required to release half the haemoglobin ( $50 \%$ lysis) of the erythrocytes. It is estimated graphically by plotting percentage lysis versus toxin volume on a log-probit graph (Alouf et al., 1965).

SDS-polyacrylamide gel electrophoresis and immunoblotting. Samples $(1 \mathrm{ml})$ of culture supernates from strains of L. monocytogenes and $L$. ivanovii grown in charcoal-treated broth (containing 200-500 HU), supplemented with cysteine $(20 \mathrm{mM})$, were incubated for $30 \mathrm{~min}$ at $37^{\circ} \mathrm{C}$ with $0.5 \mathrm{ml}$ of SRBC suspension $\left(6 \times 10^{8} \mathrm{ml}^{-1}\right)$ in PBS $\mathrm{pH}$ 6.0. For strain CIP $82110^{\top}$ and strains of $L$. seeligeri, the same procedure was applied after ultrafiltration at $4{ }^{\circ} \mathrm{C}$ in an Amicon cell apparatus, using an Amicon PM30 membrane. After complete lysis, the ghosts were sedimented at $12000 \mathrm{~g}$ for $15 \mathrm{~min}$ at $4{ }^{\circ} \mathrm{C}$, and the supernate discarded. Cell pellets were then washed twice in PBS $\mathrm{pH} 6.0$, and dissolved in $50 \mu \mathrm{l}$ of $10 \% \mathrm{SDS}$ in water. Membrane-associated proteins (about $100 \mu \mathrm{g}$ per well) were then analysed by SDS-PAGE, as described by Laemmli (1970). Samples of $50 \mu \mathrm{l}$ were added to $50 \mu \mathrm{l}$ of $2 \%$ SDS, $5 \%(\mathrm{v} / \mathrm{v})$ mercaptoethanol, $10 \%(\mathrm{v} / \mathrm{v})$ glycerol and $0.002 \%$ bromophenol blue in $0.1 \mathrm{M}-\mathrm{Tris} / \mathrm{HCl}$ buffer $(\mathrm{pH} 6.8)$. This mixture was boiled for $90 \mathrm{~s}$ and electrophoresis was performed in a linear gradient of $7.5-25 \%(\mathrm{w} / \mathrm{v})$ acrylamide at $5 \mathrm{~mA}$ for $15 \mathrm{~h}$. The proteins were electrophoretically transferred to nitrocellulose sheets (BA 85, Schleicher \& Schüll) as described by Kyhse-Andersen (1984). The sheets were incubated for $1 \mathrm{~h}$ at room temperature with shaking in $50 \mathrm{~mm}$-Tris, $150 \mathrm{mM}-\mathrm{NaCl}$ solution $(\mathrm{pH} 8.0)$ containing $5 \%(\mathrm{w} / \mathrm{v})$ dried skim milk (Régilait) prior to $1 \mathrm{~h}$ incubation in anti-listeriolysin $\mathrm{O}$ serum diluted (1 in 20) in the same buffer. The sheets were then washed eight times in the same milk buffer before addition of $20 \mathrm{ml}$ milk buffer containing $1 \mu \mathrm{Ci}(37 \mathrm{kBq})$ of ${ }^{125}$ I-protein-A kindly prepared by R. Predeleanu (Institut Pasteur, Paris). Shaking was continued for an additional hour and then the filters were washed six times in the same buffer supplemented with $0.1 \%$ Triton $\mathrm{X}$ 100. The filters were dried at $80^{\circ} \mathrm{C}$ and then autoradiographed using Kodak X-O-Mat (SO-282) film (Eastman Kodak).

Anti-listeriolysin $O$ serum and anti-SLO sera. Female albino rabbits $(3 \mathrm{~kg})$, supplied by Iffa-Credo, were immunized by injecting subcutaneously $75 \mu \mathrm{g}$ of highly purified listeriolysin $\mathrm{O}$ prepared as previously described (Geoffroy et al., 1987), emulsified in complete Freund's adjuvant, on days 0, 7 and 14, and in incomplete Freund's 


\section{Table 1. Haemolysin production by Listeria strains}

\begin{tabular}{|c|c|c|c|c|}
\hline Strain* & Serovar & $\begin{array}{l}\text { Haemolytic } \\
\text { phenotype on } \\
\text { blood agar† }\end{array}$ & $\begin{array}{c}\text { Haemolytic } \\
\text { activity in } \\
\text { untreated broth } \ddagger\end{array}$ & $\begin{array}{c}\text { Haemolytic activity } \\
\text { in charcoal-treated } \\
\text { broth } \ddagger\end{array}$ \\
\hline \multicolumn{5}{|c|}{ L. monocytogenes } \\
\hline EGD & $1 / 2 \mathrm{a}$ & +++ & 220 & 1500 \\
\hline N 3636 & $1 / 2 \mathrm{a}$ & ++ & 30 & 400 \\
\hline N 62262 & $1 / 2 a$ & ++ & 25 & 300 \\
\hline N 8018 & $4 b$ & ++ & 20 & 200 \\
\hline N 74217 & $1 / 2 b$ & ++ & 25 & 250 \\
\hline N 2661 & $4 \mathrm{~b}$ & ++ & 30 & 250 \\
\hline L 028 & $1 / 2 \mathrm{c}$ & ++ & 30 & 800 \\
\hline SLCC 4324 & $4 \mathrm{~b}$ & ++ & 20 & 400 \\
\hline SLCC 5156 & $1 / 2 a$ & $+t$ & 25 & 220 \\
\hline SLCC 3551 & $4 \mathrm{~b}$ & ++ & 25 & 350 \\
\hline SLCC 5132 & $1 / 2 a$ & ++ & 30 & 350 \\
\hline CIP $82110^{\mathrm{T}}$ & $1 / 2 a$ & - & 0 & 10 \\
\hline \multicolumn{5}{|l|}{ L. ivanovii } \\
\hline SLCC 4121 & 5 & +++ & 2500 & 2500 \\
\hline CIP $7842^{\mathrm{T}}$ & 5 & +++ & 2750 & 2500 \\
\hline \multicolumn{5}{|l|}{ L. seeligeri } \\
\hline CIP $100100^{\mathrm{T}}$ & $1 / 2$ & + & 0 & 22 \\
\hline SLCC 3503 & $1 / 2$ & + & 0 & 30 \\
\hline SLCC 4152 & $1 / 2$ & + & 0 & 25 \\
\hline SLCC 3990 & $1 / 2$ & + & 0 & 9 \\
\hline SLCC 3502 & $1 / 2$ & + & 0 & 10 \\
\hline \multicolumn{5}{|l|}{ L. innocua } \\
\hline CIP $8011^{\mathrm{T}}$ & 6 & - & 0 & 0 \\
\hline SLCC 6462 & ND & - & 0 & 0 \\
\hline SLCC 4202 & ND & - & 0 & 0 \\
\hline SLCC 4213 & ND & - & 0 & 0 \\
\hline SLCC 6466 & ND & - & 0 & 0 \\
\hline \multicolumn{5}{|l|}{ L. welshimeri } \\
\hline SLCC $5334^{\mathrm{T}}$ & 6 & - & 0 & 0 \\
\hline SLCC 5871 & 6 & - & 0 & 0 \\
\hline
\end{tabular}

ND, Not determined.

* Source of strains: EGD, Trudeau Institute, NY, USA; N, Hôpital Necker, Paris, France; L 028, Ramon y Cajal Collection, Madrid, Spain; SLCC, Special Listeria Culture Collection, Würzburg, Federal Republic of Germany; CIP, Collection de l'Institut Pasteur, Paris, France.

+ Haemolytic phenotypes on $5 \%$ horse blood-tryptic soy agar: hyperhaemolytic $(+++)$, haemolytic $(++)$, weakly haemolytic $(+)$, nonhaemolytic $(-)$.

$\ddagger$ The haemolytic activity $\left(\mathrm{HU} \mathrm{ml}^{-1}\right.$ ) was estimated at the peak production. Four to five determinations were made. The results of a representative experiment are shown here.

adjuvant on day 21. Blood was collected 2 weeks after the last injection. The anti-SLO serum (no. 525) was a hyperimmune serum previously described by Alouf et al. (1965).

Inhibition of haemolytic activity. Culture supernates were treated according to several procedures prior to haemolysin titration. Samples $(1 \mathrm{ml})$ of the supernates diluted in PBS, $\mathrm{pH} 6 \cdot 0$, to contain $30 \mathrm{HU}$ were incubated for $30 \mathrm{~min}$ : (i) at $37^{\circ} \mathrm{C}$ with $10 \mu \mathrm{l}$ of various dilutions of cholesterol $\left(1 \mathrm{mg} \mathrm{ml}{ }^{-1}\right)$ in ethanol; (ii) at $22^{\circ} \mathrm{C}$ with the thiol-group reagent $\mathrm{HgCl}_{2}$ (Sigma), at a final concentration of $10 \mathrm{~mm}$ in $\mathrm{PBS}, \mathrm{pH} \mathrm{6.0}$; (iii) at $37^{\circ} \mathrm{C}$ with hyperimmune horse anti-SLO serum (no. 525) or nonimmune horse serum (Gibco) diluted to 1 in 10 . The haemolytic activity was then measured as described above.

\section{RESULTS AND DISCUSSION}

The 12 strains of $L$. monocytogenes tested produced haemolytic factor when cultured in charcoal-treated broth (Table 1). The peak of haemolytic titres in the culture supernates ranged from 200 to $800 \mathrm{HU} \mathrm{ml}^{-1}$, except for strain EGD (about $1500 \mathrm{HU} \mathrm{ml}^{-1}$ ), and the type strain ATCC $82110^{\mathrm{T}}$ (about $10 \mathrm{HU} \mathrm{ml}^{-1}$ ). These levels corresponded to the haemolytic phenotypes on 

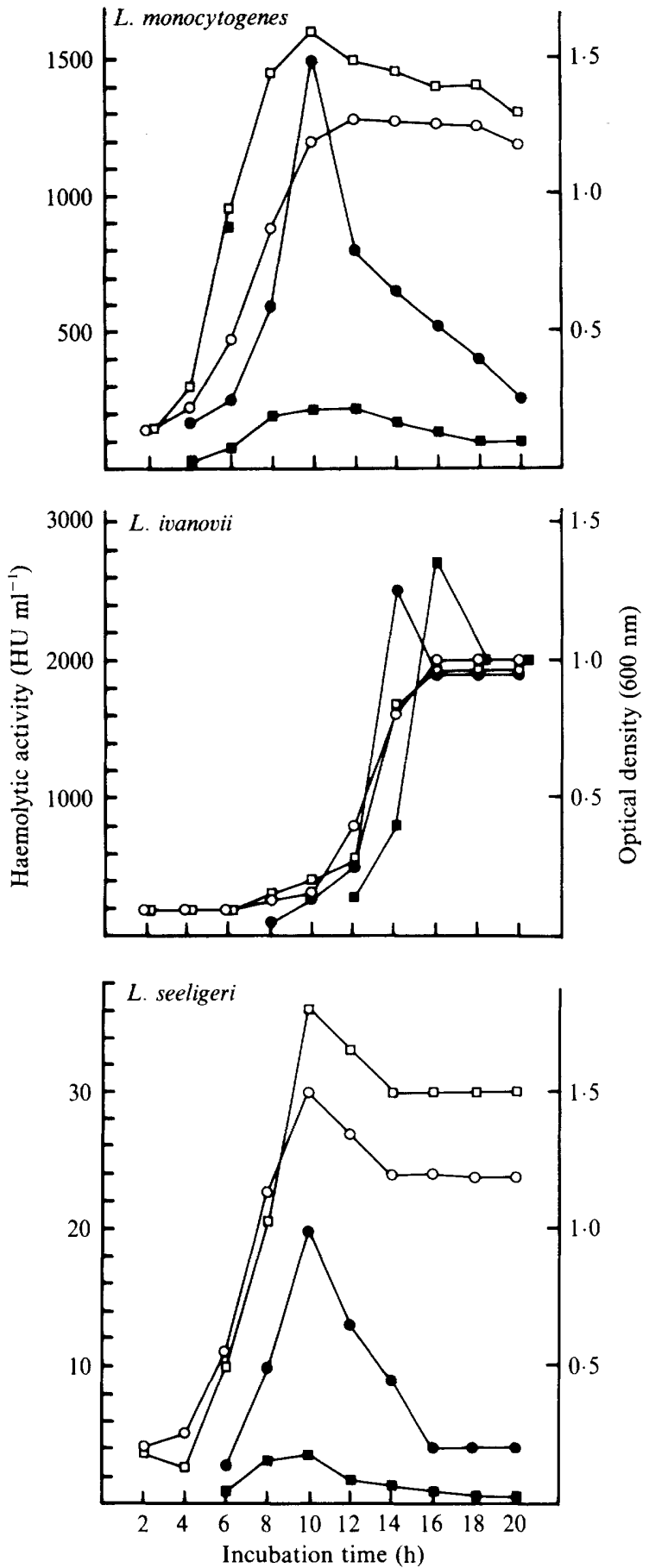

Fig. 1. Kinetics of haemolysin production in vitro. L. monocytogenes (strain EGD), L. ivanovii (strain SLCC $7842^{\mathrm{T}}$ ) and L. seeligeri (strain CIP $100100^{\mathrm{T}}$ ) were cultured in proteose-peptone broth $(\square, \boldsymbol{\square})$ or in charcoal-treated broth $(\mathrm{O}, \bullet)$. Bacterial growth was followed by optical density at $600 \mathrm{~nm}$ (open symbols) and haemolytic activity was titrated in supernates (solid symbols). The kinetics of haemolysin production was similar for the other strains of $L$. monocytogenes, $L$. ivanovii and $L$. seeligeri. The peak of haemolytic activity was reached by $8-10 \mathrm{~h}$ for $L$. monocytogenes and $L$. seeligeri, and by $14-16 \mathrm{~h}$ for $L$. ivanovii. Three to four determinations were made for each strain. The results of a representative experiment are shown here. 
blood agar since strain EGD was hyperhaemolytic and the type strain ATCC $82110^{\mathrm{T}}$ was nonhaemolytic, whereas the other strains were similarly haemolytic in this medium (Table 1). The haemolytic activity was strongly enhanced in charcoal-treated broth as compared with untreated broth (Table 1). The increase of haemolytic activity in charcoal-treated broth cannot be attributed to a difference in bacterial growth, since bacterial yield was better in untreated broth. Indeed, for all L. monocytogenes strains, the titres of viable bacteria after an $18 \mathrm{~h}$ incubation at $37^{\circ} \mathrm{C}$ ranged from $5 \times 10^{7}$ c.f.u. $\mathrm{ml}^{-1}$ to $5 \times 10^{8}$ c.f.u. $\mathrm{ml}^{-1}$ in charcoal-treated medium and from $5 \times 10^{8}$ c.f.u. $\mathrm{ml}^{-1}$ to $1 \times 10^{9}$ c.f.u. $\mathrm{ml}^{-1}$ in untreated broth. By studying the kinetics of haemolysin production for L. monocytogenes EGD (Fig. 1), it was further established that the peak of haemolytic activity in culture supernates was reached by $8-10 \mathrm{~h}$ at the end of the exponential phase of bacterial growth. Then a sharp drop of the haemolytic activity was observed, declining to a significantly lower level after $20 \mathrm{~h}$ incubation.

$L$. ivanovii strains produced high levels of haemolytic activity when cultured in either charcoal-treated or untreated broth (Table 1). L. ivanovii (strain CIP $7842^{\mathrm{T}}$ ) behaved differently from $L$. monocytogenes with respect to the kinetics of haemolysin production (Fig. 1). The haemolytic activity was optimal at $14-16 \mathrm{~h}$ and then declined slowly at the end of the exponential phase of growth. For $L$. seeligeri strains, low levels of haemolytic activity $(9-30 \mathrm{HU}$ $\mathrm{ml}^{-1}$ ) were detected in the culture supernates of bacteria grown in charcoal-treated broth (Table 1). These values correlated well with the weakly haemolytic phenotypes on blood agar (Table 1). As shown above for $L$. monocytogenes, the haemolytic activity for $L$. seeligeri (strain CIP $100100^{\mathrm{T}}$ ) reached a maximum titre by $8-10 \mathrm{~h}$ and then rapidly declined as soon as bacterial exponential growth ceased (Fig. 1). Finally, no haemolytic activity was detected in the supernates of five strains of $L$. innocua or two strains of $L$. welshimeri cultured in untreated or charcoal-treated broth (Table 1).

Since it is known that the EGD strain of L. monocytogenes produces a thiol-dependent exotoxin, listeriolysin O (Geoffroy et al., 1987), supernates obtained from other strains of $L$. monocytogenes, and from those of $L$. ivanovii and $L$. seeligeri, were examined for the presence of thiol-dependent haemolysin. The haemolytic activity of all culture supernates was totally abolished by the following treatments: (i) incubation $\left(30 \mathrm{~min}\right.$ at $\left.37^{\circ} \mathrm{C}\right)$ with cholesterol $(10 \mathrm{ng}$ cholesterol $\left.\mathrm{HU}^{-1}\right)$; (ii) incubation $\left(30 \mathrm{~min}\right.$ at $22^{\circ} \mathrm{C}$ ) with a thiol-group reagent, $\mathrm{HgCl}_{2}(1 \mathrm{mM})$, with restoration of haemolytic activity by further incubation with 2 mM-cysteine; (iii) incubation $\left(30 \mathrm{~min}\right.$ at $\left.37^{\circ} \mathrm{C}\right)$ with anti-SLO $(1$ in 10$)$. These results indicate that the haemolytic factors produded by $L$. monocytogenes, $L$. ivanovii and $L$. seeligeri share the classical properties of thiol-dependent toxins (Alouf \& Geoffroy, 1984). The production by L. monocytogenes, $L$. ivanovii, and $L$. seeligeri of an exotoxin antigenically related to listeriolysin $O$ was confirmed by Western-blot analysis using a rabbit immune serum raised against highly purified listeriolysin $\mathrm{O}$. It was shown that all strains of $L$. monocytogenes, including the type-strain CIP $82110^{\mathrm{T}}$, produced a $60 \mathrm{kDa}$ protein recognized by this immune serum (Fig. $2 a$ ). This also holds true for $L$. ivanovii and $L$. seeligeri strains (Fig. $2 b$ ).

The production of a $60 \mathrm{kDa}$ thiol-dependent toxin, listeriolysin $\mathrm{O}$, by all strains of L. monocytogenes is at a variance with the results of Parrisius et al. (1986). These authors failed to demonstrate SLO-like haemolysin in most strains of $L$. monocytogenes, including four strains used here (SLCC 4324, SLCC 5156, SLCC 3551, SLCC 5132). Our results show the influence of culture conditions upon the level of toxin produced, as already reported for strain EGD (Geoffroy et al., 1987), and this may explain this discrepancy. The low amount of iron may influence the expression of the gene(s) encoding for listeriolysin $\mathrm{O}$, as suggested by previous observations (Cowart \& Foster, 1981; Cowart \& Foster, 1985; Sword, 1966). However, the actual reasons for the increase of haemolytic activity when bacteria are grown in charcoaltreated broth remain unknown. Our results are in full agreement with those reported by Mengaud et al. (1988), who showed, by using a DNA probe under stringent conditions, that the structural gene of listeriolysin $\mathrm{O}$ is present in all L. monocytogenes strains tested. The data presented here support the view that listeriolysin $\mathrm{O}$ is the major factor responsible for the haemolytic phenotype of colonies on blood agar, as is strongly suggested by the observation that mutants derived by transposon insertion in the structural gene of listeriolysin $O$ appear 

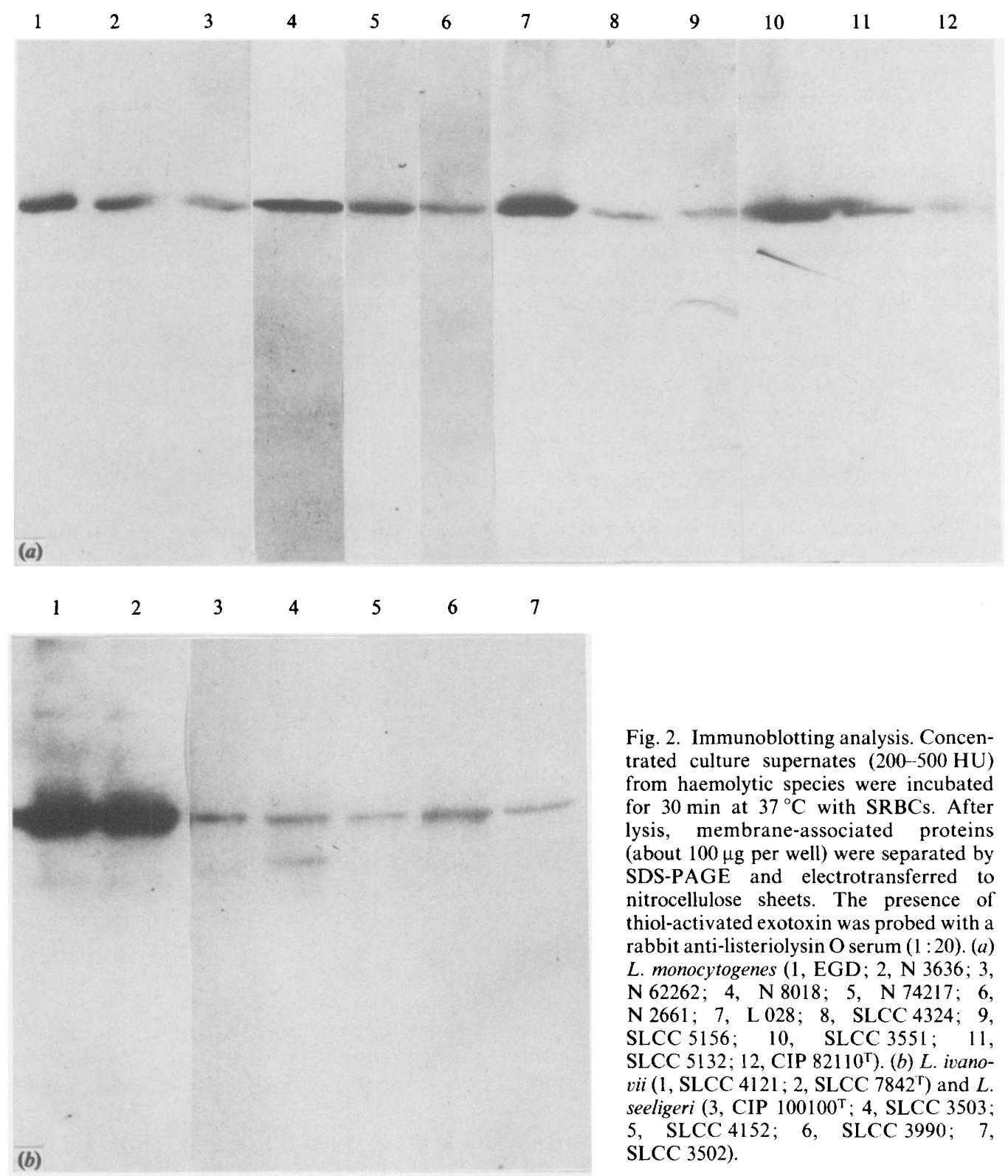

Fig. 2. Immunoblotting analysis. Concentrated culture supernates $(200-500 \mathrm{HU})$ from haemolytic species were incubated for $30 \mathrm{~min}$ at $37^{\circ} \mathrm{C}$ with SRBCs. After lysis, membrane-associated proteins (about $100 \mu \mathrm{g}$ per well) were separated by SDS-PAGE and electrotransferred to nitrocellulose sheets. The presence of thiol-activated exotoxin was probed with a rabbit anti-listeriolysin $\mathrm{O}$ serum $(1: 20)$. (a) L. monocytogenes (1, EGD; $2, \mathrm{~N} 3636 ; 3$,

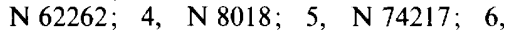
N 2661；7， L 028；8, SLCC 4324; 9, SLCC 5156; 10, SLCC 3551; 11, SLCC 5132; 12, CIP 82110 $)$, (b) L. ivanovii $\left(1\right.$, SLCC $\left.4121 ; 2, \operatorname{SLCC} 7842^{\mathrm{r}}\right)$ and $L$. seeligeri $\left(3\right.$, CIP $100100^{\mathrm{T}} ; 4$, SLCC 3503 ; 5, SLCC 4152; 6, SLCC 3990; 7, SLCC 3502).

nonhaemolytic on blood agar (Gaillard et al., 1986; Kathariou et al., 1987; Portnoy et al., 1988).

With respect to the other haemolytic species, we found that $L$. ivanovii produces high levels of a thiol-dependent exotoxin as previously described (Parrisius et al., 1986). Strains of $L$. seeligeri produced low levels of haemolytic activity $\left(9-30 \mathrm{HU} \mathrm{ml}^{-1}\right)$ in charcoal-treated broth. We were able to identify for the first time the nature of this haemolytic factor also as a thiol-activated exotoxin with an $M_{\mathrm{r}}$ of about 60000 , antigenically related to listeriolysin O and SLO (Fig. 2). Using a DNA probe in stringent conditions, Mengaud et al. (1988) detected the listeriolysin O gene only in L. monocytogenes, indicating that there exists noticeable divergence between the genes encoding for thiol-dependent exotoxins in the three haemolytic species of the genus Listeria. On the basis of our results showing the existence of thiol-dependent toxins in $L$. ivanovii and $L$. seeligeri, we propose to designate these two toxins as listeriolysin $\mathrm{O}$ var. ivanovii and 
listeriolysin $\mathrm{O}$ var. seeligeri, according to the nomenclature recommended by Bernheimer (1976).

We gratefully acknowledge Dr P. Cossart and Dr J. Mengaud for helpful discussion, Dr F. Baquero, Dr J. Rocourt, Dr A. Schrettenbrunner and Dr E. Espaze for providing some strains used in the present work, and Dr J. P. Craig (State University of New York) for reviewing the manuscript. Serovars of the clinical isolates (from the Hospital Necker Collection) were kindly determined by Dr E. Espaze and Dr A. Courtieu (Centre National des Listeria, Nantes, France) and the iron assays were performed by Dr P. Chappuis (Hôpital Lariboisière, Paris). We extend our grateful appreciation to I. Razafimanantzoa and D. Ahu for their excellent technical assistance, and to L. Oussadi and M. L. Fourneaux for typing the manuscript. This work was supported by grants to P. Berche (DES 3009 from the Direction de l'Enseignement Supérieur, Université Paris V, and CRE 853004 from Institut National de la Santé et de la Recherche Médicale).

\section{REFERENCES}

Alouf, J. E. \& Geofroy, C. (1984). Structure activity relationships in sulfhydryl-activated toxins. In $\mathrm{BaC}$ terial Protein Toxins, pp. 165-171. Edited by J. E. Alouf, F. J. Fehrenbach, J. H. Freer \& J. Jeljaszewicz. London: Academic Press.

Alouf, J. E., Viette, M., Corvazier, R. \& Raynaud, M. (1965). Preparation et propriétés des sérums de chevaux antistreptolysine $\mathrm{O}$. Annales de l'Institut Pasteur 108, 476-500.

BerNheimer, A. W. (1976). Sulfhydryl-activated toxins. In Mechanisms in Bacterial Toxinology, pp. 85 97. Edited by A. W. Bernheimer. New York: John Wiley.

COWART, R. E. \& Foster, B. G. (1981). The role of iron in the production of haemolysin by Listeria monocytogenes. Current Microbiology 6, 287-290.

Cowart, R. E. \& Foster, B. G. (1985). Differential effects of iron on the growth of Listeria monocytogenes: minimum requirements and mechanism of acquisition. Journal of Infectious Diseases 151, 721730 .

Gaillard, J. L., Berche, P. \& Sansonetti, P. (1986). Transposon mutagenesis as a tool to study the role of haemolysin in the virulence of Listeria monocytogenes. Infection and Immunity 52, 50-55.

Gaillard, J. L., Berche, P., Mounier, J., Richard, S. \& SANSONETTI, P. (1987). In vitro model of penetration and intracellular growth of Listeria monocytogenes in the human enterocyte-like cell line Caco-2. Infection and Immunity 55, 2822-2829.

Geoffroy, C., Gaillard, J. L., Alouf, J. E. \& BERCHE, P. (1987). Purification, characterization and toxicity of the sulfhydryl-activated haemolysin listeriolysin $\mathrm{O}$ from Listeria monocytogenes. Infection and Immunity 55, 1641-1646.

Kathariou, S., Metz, P., Hof, H. \& Goebel, W. (1987). Tn916-induced mutations in the hemolysin determinant affecting virulence of Listeria monocvtogenes. Journal of Bacteriology 169, 1291-1297.

KenOE, M. \& Timmis, K. N. (1984). Cloning and expression in Escherichia coli of the streptolysin O determinant from Streptococcus pyogenes: characterization of the cloned streptolysin $\mathrm{O}$ determinant and demonstration of the absence of substantial homology with determinants of other thiol-activated toxins. Infection and Immunity 43, 804-810.
Kuhn, M., Kathariou, S. \& Goebel, W. (1988). Hemolysin supports survival but not entry of the intracellular bacterium Listeria monocytogenes. Infection and Immunity 56, 79-82.

K YHSE-ANDERSEN, J. (1984). Electroblotting of multiple gels: a simple apparatus without buffer tank for rapid transfer of proteins from polyacrylamide to nitrocellulose. Journal of Biochemistry and Biophysics Methods 10, 203-209.

LAEMMLI, U. K. (1970). Cleavage of structural proteins during the assembly of the head of bacteriophage T4. Nature, London 227, 680-685.

Mengaud, J., Chenevert, J., Geoffroy, C., GailLARD, J. L. \& COSSART, P. (1987). Identification of the structural gene encoding the SH-activated haemolysin of Listeria monocytogenes: listeriolysin O is homologous to streptolysin $\mathrm{O}$ and pneumolysin. Infection and Immunity 55, 3225-3227.

Mengaud, J., Vicente, M. F., Chenevert, J., Pereira, J. M., Geoffroy, C., Gicquel-Sanzey, B., Baquero, F., Perez-Diaz, J. C. \& Cossart, P. (1988). Expression in Escherichia coli and sequence analysis of the listeriolysin O determinant of Listeria monocytogenes. Infection and Immunity 56, 766-772. Parrisius, J., Bhakdi, S., Roth, M., Tranum-Jensen, J., Goebel, W. \& Seeliger, H. P. R. (1986). Production of listeriolysin by beta-hemolytic strains of Listeria monocytogenes. Infection and Immunity 51, 314-319.

Portnoy, D. A., JACKs, P. S. \& Hinrichs, D. J. (1988). Role of hemolysin for the intracellular growth of Listeria monocytogenes. Journal of Experimental Medicine 167, 1459-1471.

SwORD, C. P. (1966). Mechanisms of pathogenesis in Listeria monocytogenes infection. I. Influence of iron. Journal of Bacteriology 92, 536-542.

Vicente, M. F., Baquero, F. \& Perez-Diaz, J. C. (1985). Cloning and expression of the Listeria monocytogenes haemolysin in E. coli. FEMS Microbiology Letters 30, 77-79.

Walker, J. A., Allen, R. L., Falmagne, P., Johnson, M. K. \& BoulnoIs, G. J. (1987). Molecular cloning, characterization and complete nucleotide sequence of the gene for pneumolysin, the sulfhydryl-activated toxin of Streptococcus pneumoniae. Infection and Immunity 55, 1184-1189. 